\title{
Top-Down Synthesis of NaP Zeolite from Natural Zeolite for the Higher Removal Efficiency of $\mathrm{Cs}$, $\mathrm{Sr}$, and $\mathrm{Ni}$
}

\author{
Seokju Hong ${ }^{1}$ and Wooyong Um ${ }^{1,2,3, *}$ \\ 1 Division of Advanced Nuclear Engineering (DANE), Pohang University of Science and \\ Technology (POSTECH), 77 Chongam-ro, Nam-gu, Pohang 790-784, Korea; frederic@postech.ac.kr \\ 2 Division of Environmental Sciences and Engineering (DESE), Pohang University of Science and \\ Technology (POSTECH), 77 Chongam-ro, Nam-gu, Pohang 790-784, Korea \\ 3 Nuclear Environmental Technology Institute (NETI), Pohang University of Science and \\ Technology (POSTECH), Pohang, Gyeongbuk 790-784, Korea \\ * Correspondence: wooyongum@postech.ac.kr; Tel.: +82-54-279-9563; Fax: +82-54-279-9559
}

Citation: Hong, S.; Um, W.

Top-Down Synthesis of NaP Zeolite from Natural Zeolite for the Higher Removal Efficiency of Cs, Sr, and Ni. Minerals 2021, 11, 252. https:// doi.org/10.3390/min11030252

Academic Editors: Natale Perchiazzi and María Ángeles Martín-Lara

Received: 13 February 2021

Accepted: 25 February 2021

Published: 28 February 2021

Publisher's Note: MDPI stays neutral with regard to jurisdictional claims in published maps and institutional affiliations.

Copyright: (c) 2021 by the authors. Licensee MDPI, Basel, Switzerland. This article is an open access article distributed under the terms and conditions of the Creative Commons Attribution (CC BY) license (https:/ / creativecommons.org/licenses/by/ $4.0 /)$.

\begin{abstract}
A solid phase of natural zeolite was transformed to Na-zeolite P (NaP zeolite) by a "top-down approach" hydrothermal reaction using $3 \mathrm{M}$ of $\mathrm{NaOH}$ solution in a $96{ }^{\circ} \mathrm{C}$ oven. Timedependent X-ray diffraction (XRD), Fourier-transform infrared (FT-IR), XRF, and scanning electron microscopy (SEM) analysis as well as kinetic, isotherm, and cation exchange capacity experiments were performed to understand the mechanism of mineral transition from natural zeolite to NaP zeolite. The XRD crystal peaks of the natural zeolite decreased (decrystallization phase) first, and then the NaP zeolite XRD crystal peaks increased gradually (recrystallization phase). From the XRF results, the dissolution rate of $\mathrm{Si}$ was slow in the recrystallization phase, while it was rapid in the decrystallization phase. The specific surface area measured by BET analysis was higher in NaP zeolite $\left(95.95 \mathrm{~m}^{2} / \mathrm{g}\right)$ compared to that of natural zeolite $\left(31.35 \mathrm{~m}^{2} / \mathrm{g}\right)$. Furthermore, pore structure analysis confirmed that $\mathrm{NaP}$ zeolites have more micropores than natural zeolite. In the kinetic experiment, the results showed that the natural zeolite and $\mathrm{NaP}$ zeolite were well matched with a pseudosecond-order kinetic model, and reached equilibrium within $24 \mathrm{~h}$. The isotherm experiment results confirmed that both zeolites were well matched with the Langmuir isotherm, and the maximum removal capacity $\left(\mathrm{Q}_{\max }\right)$ values of $\mathrm{Sr}$ and $\mathrm{Ni}$ were highly increased in $\mathrm{NaP}$ zeolite. In addition, the cation exchange capacity (CEC) experiment showed that $\mathrm{NaP}$ zeolite has an enhanced CEC of $310.89 \mathrm{cmol} / \mathrm{kg}$ compared to natural zeolite $(\mathrm{CEC}=119.19 \mathrm{cmol} / \mathrm{kg})$. In the actual batch sorption test, $\mathrm{NaP}$ zeolite $(35.3 \mathrm{mg} / \mathrm{g})$ still showed high Cs removal efficiency though it was slightly lower than the natural zeolite $(39.0 \mathrm{mg} / \mathrm{g})$. However, in case of $\mathrm{Sr}$ and $\mathrm{Ni}, \mathrm{NaP}$ zeolite $(27.9 \mathrm{and} 27.8 \mathrm{mg} / \mathrm{g}$, respectively) showed a much higher removal efficiency than natural zeolite ( 4.9 and $5.5 \mathrm{mg} / \mathrm{g}$ for $\mathrm{Sr}$ and $\mathrm{Ni}$, respectively). This suggests that $\mathrm{NaP}$ zeolite, synthesized by a top-down desilication method, is more practical to remove mixed radionuclides from a waste solution.
\end{abstract}

Keywords: top-down synthesis; natural zeolite; NaP zeolite; desilication mechanism; radionuclides

\section{Introduction}

Over the past few decades, low- and intermediate-level radioactive wastes composed of long-lived radionuclides such as ${ }^{137} \mathrm{Cs},{ }^{90} \mathrm{Sr}$, and ${ }^{63} \mathrm{Ni}$ have been generated extensively during nuclear power plant (NPP) operations. Because of significant nuclear accidents such as Chernobyl and Fukushima, issues with NPP-generated radioactive wastes have become much more serious [1]. Among them, ${ }^{137} \mathrm{Cs}$ and ${ }^{90} \mathrm{Sr}$ have long-term radio-biological risks, because ${ }^{137}$ Cs can easily transfer to human muscles through the $\mathrm{K}^{+}$channel [2], and ingested ${ }^{90} \mathrm{Sr}$ can be deposited on the surface of bone in which Ca can be replaced with ${ }^{90} \mathrm{Sr}$ [3]. Both ${ }^{137} \mathrm{Cs}$ and ${ }^{90} \mathrm{Sr}$ are the most common fission products produced by nuclear fission in nuclear reactors or nuclear weapons. The primary source of ${ }^{63} \mathrm{Ni}$ in the environment results from neutron-activated stable ${ }^{62} \mathrm{Ni}$ present in structural components of 
nuclear reactor vessels [4]. However, the biological risk of ${ }^{63} \mathrm{Ni}$ is not high compared with those of ${ }^{137} \mathrm{Cs}$ and ${ }^{90} \mathrm{Sr}$. Nonetheless, further study is needed to remove ${ }^{63} \mathrm{Ni}$, because ${ }^{63} \mathrm{Ni}$ is considered as a primary radionuclide that is generated from NPP metal waste, owing to its high specific activity of $2.1 \mathrm{TBq} / \mathrm{g}$.

To resolve these issues, various types of materials, including activated carbon [5], potassium copper hexacyanoferrate [6], graphene oxide [7], and bentonite clay [8], have been tested to discern their applicability as sorbents. Among them, zeolite, a micro-nano sized porous aluminosilicate mineral, has been widely studied as a sorbent to remove different types of radionuclides as well as other heavy metals, and works well because of its large specific surface area, high sorption affinity, and high selectivity [9]. However, the removal efficiency of zeolites is strongly affected by the ionic strength, $\mathrm{pH}$, and the type and concentration of ions in solution. For example, Munthali et al. [9] showed that mordenite had a very high $\mathrm{Cs}^{+}$adsorption efficiency in both $\mathrm{NaNO}_{3}$ and $\mathrm{KNO}_{3}$ solutions (0.05-0.5 M), but its $\mathrm{Sr}^{2+}$ adsorption efficiency was quite poor, particularly in $\mathrm{KNO}_{3}$ solutions. Conversely, they also demonstrated that faujasite X-zeolites had very high $\mathrm{Sr}^{2+}$ adsorption efficiency in both $\mathrm{NaNO}_{3}$ and $\mathrm{KNO}_{3}$ solutions $(0.05,0.1$, and $0.5 \mathrm{M})$, but very poor adsorption efficiencies were found for $\mathrm{Cs}^{+}$, especially in a $\mathrm{KNO}_{3}$ concentration of $0.5 \mathrm{M}$ [9]. Thus, many studies have been carried out to synthesize new types of zeolite for improved removal efficiency. Although most of these syntheses utilize the so-called "bottom-up approach", in this study, we explore the "top-down approach" for the alternative preparation of synthetic zeolites (Figure 1).

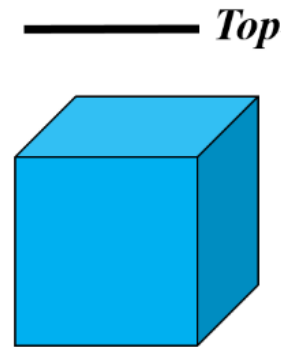

Bulk size natural zeolite

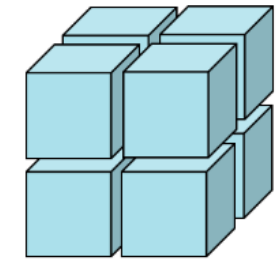

Modified natural zeolite

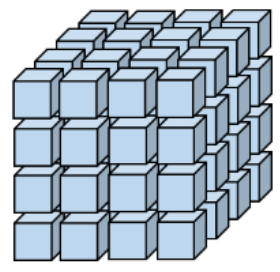

Nano/micro structures

Bottom-up approach

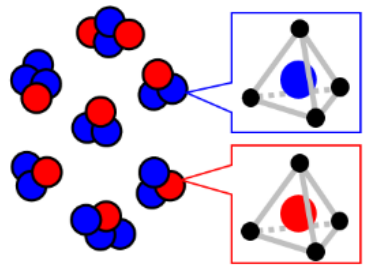

Tetrahedron

Si-Al clusters

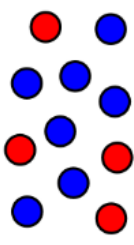

$\mathrm{Si}(\mathrm{OH})_{4}$

$\mathrm{Al}(\mathrm{OH})_{4}$

Figure 1. Schematic diagrams of "top-down and bottom-up approaches" for the synthesis of hierarchical porous zeolites.

Almost all of the previous researches used a "bottom-up approach" when they synthesized a new zeolite. Specifically, for the bottom-up method, precursors containing Si and $\mathrm{Al}$ are mixed to form either a gel or fine powder to build a new type of aluminosilicate structure at high $\mathrm{pH}$ and temperature conditions. In addition, bottom-up synthesis has the advantage of lowering impurity formation. Nonetheless, this method has difficulties with mass production, particularly due to the high costs of the initial Si and Al precursors, and maintaining products in a homogeneous state is very difficult in large-scale pressure vessels.

Because of this, in terms of practicality, the "top-down approach" should certainly be considered as a promising method, because it has significant advantages that enable process simplification, mass production, and unit cost saving. Most researchers have synthesized zeolites as fine powder, but in this study, we focused on granular-sized natural zeolites for the top-down synthesis of $\mathrm{NaP}$ zeolites. These granular-sized natural zeolites are also expected to solve the difficulty in practical application (i.e., dust problems and powder needing to be centrifuged for washing) compared to the powder-sized zeolites used as initial substrates.

Research has been undertaken regarding the solid phase of zeolites changed through a recrystallization process, and the "top-down approach" is also based on this recrystallization process [10]. However, should this method be utilized, the selection of the initial bulk zeolite type as well as the optimization parameters are very important. Thus, care must be 
taken to choose suitable experimental conditions; otherwise, the process can become costly and complex, and the removal efficiency of the newly formed zeolite can be reduced.

Of the various types of synthetic zeolites, $\mathrm{NaP}\left(\mathrm{Na}_{6} \mathrm{Al}_{6} \mathrm{Si}_{10} \mathrm{O}_{32} \cdot 15 \mathrm{H}_{2} \mathrm{O}\right)$ zeolite is one of the most interesting. To date, only a few researchers have attempted to modify natural zeolite to create synthetic $\mathrm{NaP}$ zeolites. Mimura and Akiba [11] synthesized NaP zeolite from natural clinoptilolite and mordenite, whereas Kang and Egashira [12] fabricated NaP zeolite from natural Korean zeolite. In addition, these natural zeolites, especially mordenite, showed very high $\mathrm{Cs}^{+}$removal efficiency compared with other natural zeolites, particularly in solutions with an ionic strength of $0.05 \mathrm{M}$ [13]. Notwithstanding, the $\mathrm{Sr}^{2+}$ and $\mathrm{Ni}^{2+}$ removal efficiencies of clinoptilolite and mordenite were found to be significantly lower than that of $\mathrm{Cs}^{+}$under the similar conditions [13-16]. The maximum $\mathrm{Sr}^{2+}$ sorption capacity of clinoptilolite was found to be $11.7 \mathrm{mg} / \mathrm{g}$. Unfortunately, although no comparative study was found for the maximum $\mathrm{Sr}^{2+}$ sorption capacity of mordenite, it showed a removal efficiency that was far less than that of clinoptilolite [11,14]. For the sorption of $\mathrm{Ni}^{2+}$, the maximum capacities of clinoptilolite and mordenite were found to be 3.1 and $5.3 \mathrm{mg} / \mathrm{g}$, respectively $[15,16]$. As a result, clinoptilolite and mordenite showed higher selectivity for the removal of $\mathrm{Cs}^{+}$than $\mathrm{Sr}^{2+}$ and $\mathrm{Ni}^{2+}$. To increase the removal efficiencies of all three target radionuclides from the same waste solution, $\mathrm{NaP}$ zeolite was synthesized using bulk-sized natural zeolite and the top-down approach, and evaluated based on batch sorption results.

\section{Materials and Methods}

\subsection{Materials}

Natural zeolite ores were obtained in Guryongpo, Pohang, South Korea (Figure S1 in the supplementary materials) and used without any further refining. The zeolite ores were crushed at the Korea Institute of Geoscience and Mineral Resources (Daejeon, Korea) and separated on the basis of size (i.e., powders were between 200 and $500 \mu \mathrm{m}$, and granularsized zeolites were between 2 and $5 \mathrm{~mm}$ ). Natural zeolite is mainly composed of clinoptilolite and mordenite [17]. Pure sodium hydroxide $(\mathrm{NaOH})$ and a high-density polyethylene (HDPE) bottle were purchased from Samchun Incorporation (Pyeongtaek, Korea). Cesium nitrate $\left(\mathrm{CsNO}_{3}\right)$, strontium nitrate $\left(\mathrm{Sr}\left(\mathrm{NO}_{3}\right)_{2}\right)$, and nickel nitrate hexahydrate $\left(\mathrm{Ni}\left(\mathrm{NO}_{3}\right)_{2} \cdot 6 \mathrm{H}_{2} \mathrm{O}\right)$ were all purchased from Sigma-Aldrich (Yong-in, Korea) and used as surrogates for targeted radionuclides, ${ }^{137} \mathrm{Cs},{ }^{90} \mathrm{Sr}$, and ${ }^{63} \mathrm{Ni}$ during batch sorption experiments.

\subsection{Synthesis of NaP Zeolite}

Powder-sized and granular-sized natural zeolites were used in quantities of $10 \mathrm{~g}$ each, and hydrothermally treated with $3 \mathrm{M}$ of $\mathrm{NaOH}$ in a $250 \mathrm{~mL}$ HDPE bottle, separately. Each bottle was then closed before being placed inside an oven at $96^{\circ} \mathrm{C}$ for various reaction times (from $10 \mathrm{~min}$ to $60 \mathrm{~h}$ ). Following these reactions, the hydrothermally treated zeolites were then washed several times with deionized (DI) water until the $\mathrm{pH}$ was neutral ( $\sim 8)$, before being dried in a $60^{\circ} \mathrm{C}$ oven for $12 \mathrm{~h}$. Independently, the powder-sized zeolites were washed using a centrifuge at $3000 \mathrm{rpm}$ for $5 \mathrm{~min}$, whereas the granular-sized zeolites were hand-washed separately. Characterization methods of X-ray diffraction (XRD), Fouriertransform infrared (FTIR), Brunauer Emmett Teller (BET), and SEM/EDS are described in the Supporting Information.

\subsection{Characterization}

Powder X-ray diffraction (XRD) measurements were undertaken using a RigakuMiniflex 600 diffractometer (Nuclear environmental laboratory, Pohang, Korea), operated at $40 \mathrm{kV}$ and $15 \mathrm{~mA}$ in the $2 \theta$ range of $5^{\circ}$ to $90^{\circ}$ at a $0.01^{\circ}$ size step using a $\mathrm{Cu} \mathrm{K} \alpha$ radiation source. The chemical compositions of the zeolites were analyzed by $\mathrm{X}$-ray fluorescence (XRF) measurements with the Bruker S4 Explorer (Graduate Institute of Ferrous Technology, Pohang, Korea). 
Fourier-transform infrared (FT-IR) spectra were acquired using a Thermo Fisher Scientific-Nicolet iS 10 spectrometer (Nuclear Environmental Laboratory, Pohang, Korea) with 32 scans measured between 650 and $3800 \mathrm{~cm}^{-1}$ at $4 \mathrm{~cm}^{-1}$ increments to analyze the chemical bonding changes in zeolites.

In order to obtain the pore properties of natural and $\mathrm{NaP}$ zeolites, both materials were analyzed via $\mathrm{N}_{2}$ adsorption/desorption isotherms measured at 77K using a BELSORP mini II (Soletek Trading Inc., Seoul, Korea). Before measurements, the solid samples were degassed under a vacuum for $12 \mathrm{~h}$ at $373 \mathrm{~K}$. The specific surface area and the pore size distribution were determined by Brunauer Emmett Teller (BET) method and Barrett Joyner Halenda $(\mathrm{BJH})$ plot, respectively. The surface area $\left(\mathrm{S}_{\mathrm{BET}}\right)$ was calculated from the adsorption branch in the $\mathrm{P} / \mathrm{P}_{0}$ range of 0.05 to 0.30 and the micropore volume was calculated by t-plot method.

A scanning electron microscope (SEM-JSM 7800F PRIME) (National Institute of Nanomaterials Technology, Pohang, Korea), coupled to an energy-dispersive spectrometer, was operated at $1 \mathrm{kV}$ to observe the changes in surface morphology as well as any elemental variations in the different zeolites.

\subsection{Batch Sorption Tests}

Various concentrations of solutions $\left(\mathrm{CsNO}_{3}, \mathrm{Sr}\left(\mathrm{NO}_{3}\right)_{2}\right.$, and $\left.\mathrm{Ni}\left(\mathrm{NO}_{3}\right)_{2} \cdot 6 \mathrm{H}_{2} \mathrm{O}\right)$ were used for the batch sorption tests. To calculate the maximum sorption capacity of both natural and $\mathrm{NaP}$ zeolites, $\mathrm{Cs}^{+}, \mathrm{Sr}^{2+}$, and $\mathrm{Ni}^{2+}$ ions were individually prepared and DI water was applied as the control solution. In addition, to simulate a "real time" scenario of Hanbit NPP in South Korea, additional sorption tests were conducted using Hanbit groundwater spiked with $\mathrm{Cs}^{+}, \mathrm{Sr}^{2+}$, and $\mathrm{Ni}^{2+}$, at either 10 or $100 \mathrm{ppm}$. The Hanbit groundwater composition can be seen in Table S1. The removal efficiency, R (\%), was calculated using Equation (1).

$$
\mathrm{R}[\%]=\frac{\mathrm{C}_{\mathrm{i}} \mathrm{C}_{\mathrm{f}}}{\mathrm{C}_{\mathrm{i}}} \times 100
$$

where $C_{i}$ and $C_{f}$ are the initial and final concentrations of radionuclides in solution, respectively. Inductively coupled plasma mass spectrometry (ICP-MS) with a PerkinElmerNexion ${ }^{\mathrm{R}}$ 350D spectrometer (Pohang University of Science and Technology, Pohang, Korea) was used to analyze the concentration of $\mathrm{Cs}^{+}, \mathrm{Sr}^{2+}$, and $\mathrm{Ni}^{2+}$ solutions, before and after sorption. As previously determined sorption kinetics for clinoptilolite and zeolite $\mathrm{NaP}$ were reported to reach equilibrium within $48 \mathrm{~h}$ [11], our batch sorption tests were conducted in duplicate, in neutral $\mathrm{pH}$ conditions for 7 days (d) at room temperature.

\subsection{Kinetics, Isotherms, and Cation Exchange Capacity}

To determine the adsorption kinetics, a pseudo-first-order kinetic model and a pseudosecond-order kinetic model were applied. The general form of pseudo-first-order is shown in Equation (2);

$$
\ln \left[Q_{e}-Q_{t}\right]=\ln Q_{e}-k_{1} t
$$

where $\mathrm{Q}$ is the amount of adsorbed solute, $\mathrm{Q}_{\mathrm{e}}$ is the value at equilibrium, $\mathrm{k}_{1}$ is the pseudofirst-order rate constant, and $t$ is the time. The general form of pseudo-second-order is shown in Equation (3);

$$
\frac{\mathrm{t}}{\mathrm{Q}_{\mathrm{t}}}=\frac{\mathrm{t}}{\mathrm{Q}_{\mathrm{e}}}+\frac{1}{\mathrm{k}_{2} \mathrm{Q}_{\mathrm{e}}^{2}}
$$

where $\mathrm{k}_{2}$ is the pseudo-second-order rate constant and $\mathrm{t}$ is the time.

To determine the adsorption isotherms, a Langmuir isotherm model and a Freundlich isotherm model were applied. The linear form of the Langmuir isotherm model is shown in Equation (4);

$$
\frac{\mathrm{C}_{\mathrm{e}}}{\mathrm{Q}_{\mathrm{e}}}=\frac{1}{\mathrm{Q}_{\max } \mathrm{K}_{\mathrm{L}}}+\frac{\mathrm{C}_{\mathrm{e}}}{\mathrm{Q}_{\max }}
$$


where $Q_{\max }$ is the maximum sorption capacity, $\mathrm{K}_{\mathrm{L}}$ is the Langmuir constant, and $\mathrm{C}_{\mathrm{e}}$ is the equilibrium concentration. The linear form of the Freundlich isotherm model is shown in Equation (5);

$$
\ln Q_{\mathrm{e}}=\ln \mathrm{K}_{\mathrm{F}}+\frac{1}{\mathrm{n}} \ln \mathrm{C}_{\mathrm{e}}
$$

where $K_{F}$ is the Freundlich constant, and $1 / n$ is the constant of sorption intensity.

To determine the cation exchange capacity, we used the ammonium acetate $\left(\mathrm{NH}_{4} \mathrm{OAc}\right)$ solution saturation method. In an $1 \mathrm{~N}$ of $\mathrm{NH}_{4} \mathrm{OAc}$ solution $(500 \mathrm{~mL}), 2 \mathrm{~g}$ of natural zeolite or $\mathrm{NaP}$ zeolite were placed and we conducted the batch uptake test for 15 days. The $\mathrm{pH}$ adjustment ( $\mathrm{pH} 7$ ) was performed with acetic acid and ammonium hydroxide. To distinguish the ion-exchange from simple ion leaching, the same experiments were conducted in $500 \mathrm{~mL}$ of DI water instead of $\mathrm{NH}_{4} \mathrm{OAc}$ solution. After the batch uptake, the concentration of cations $(\mathrm{Na}, \mathrm{K}, \mathrm{Mg}$, and $\mathrm{Ca}$ ) simply leached out into DI water was deducted from the concentration of cations $(\mathrm{Na}, \mathrm{K}, \mathrm{Mg}$, and $\mathrm{Ca}$ ) exchanged with ammonium acetate solution.

\section{Results and Discussion}

\subsection{Synthesis and characterization of NaP Zeolite and Natural Zeolite}

For comparative purposes, we used both powdered natural zeolite with size fractions between 200 and $500 \mu \mathrm{m}$ and granular natural zeolite between 2 and $5 \mathrm{~mm}$ as the initial zeolite material for the top-down synthesis approach. In the natural zeolite used, a high $\mathrm{Si} / \mathrm{Al}$ ratio $(>4)$ was confirmed because of the presence of clinoptilolite and mordenite. As such, both powdered and granular zeolites were individually placed into separate $3 \mathrm{M} \mathrm{NaOH}$ solutions, with the mixture was left to react for $60 \mathrm{~h}$ in an oven at $96{ }^{\circ} \mathrm{C}$. The details of the top-down synthesis procedure for the granular zeolites are described in Figure S2. Typically, as NaP zeolites have varied Si/Al ratios, they will undoubtedly display different properties. For example, Kang and Egashira [12] found that the cation exchange capacity of $\mathrm{NaP}$ zeolite was twice as high in comparison with those of natural clinoptilolites. This was due to the NaP zeolite being more Al rich as opposed to natural zeolite. Further, Al-rich zeolites generally have higher cation exchange capacities because of their overall negative surface charge, caused by the isomorphic substitution of $\mathrm{Al}$ for $\mathrm{Si}$ in the tetrahedral framework. Thus, we expect our NaP zeolites to possess a much higher cation exchange capacity in comparison with natural zeolite. However, Huo et al. [18] found that $\mathrm{NaP}$ zeolite can have various $\mathrm{Si} / \mathrm{Al}$ ratios. Therefore, it is imperative to evaluate the chemical properties of the $\mathrm{NaP}$ zeolite, based on the quantitative chemical analysis of $\mathrm{Si}$ and $\mathrm{Al}$.

The resulting XRD patterns of both natural and NaP zeolites are illustrated in Figure 2A. The presence of mordenite and clinoptilolite was confirmed with major reference peaks as reported by others [9]. Furthermore, the XRD peaks of opal mineral, which is commonly found in bentonite and zeolite mines, were present as found at a $2 \theta$ region between $22^{\circ}$ and $23^{\circ}$ [19-22]. Regarding the NaP zeolite, clear characteristics of the NaP zeolite were found in JCPDS (Joint Committee on Powder Diffraction Standard) reference code (39-0219) and in the literature [11]. The five main peaks (shown at $12.5^{\circ}, 17.6^{\circ}, 21.6^{\circ}, 28.2^{\circ}$, and $33.4^{\circ}$ ) were all found to match well with the major peaks of $\mathrm{NaP}$ zeolites. Among our synthesized $\mathrm{NaP}$ zeolites, the presence of the $\mathrm{NaP} 1$ zeolite was also confirmed, with two characteristic peaks at $30.8^{\circ}$ and $38.0^{\circ}$ found. Because the $\mathrm{NaP} 1$ and $\mathrm{NaP}$ phases clearly demonstrate that $\mathrm{NaP}$ zeolites were successfully synthesized, hereafter, we refer to our modified zeolite as "NaP zeolite".

The chemical compositions of natural and NaP zeolites are given in Table S2. Generally, the $\mathrm{Si} / \mathrm{Al}$ ratio of clinoptilolite varies from 3.5 to 5 because the main chemical formula of clinoptilolite $(\mathrm{Na})$ can vary from $\mathrm{Na}_{3} \mathrm{Al}_{3} \mathrm{Si}_{15} \mathrm{O}_{36} \cdot 12 \mathrm{H}_{2} \mathrm{O}$ to $\mathrm{Na}_{4} \mathrm{Al}_{4} \mathrm{Si}_{14} \mathrm{O}_{36} \cdot 12 \mathrm{H}_{2} \mathrm{O}$ [23]. On the contrary, the $\mathrm{Si} / \mathrm{Al}$ ratio of mordenite usually sits at 5 as $\mathrm{Na}_{2} \mathrm{Al}_{2} \mathrm{Si}_{10} \mathrm{O}_{24} \cdot 7 \mathrm{H}_{2} \mathrm{O}$ is the nominal chemical formula [14]. From Table S2, the Si/Al ratio of our natural zeolites sits 
around 4.36, and this $\mathrm{Si} / \mathrm{Al}$ ratio is the result of the combination of clinoptilolite, mordenite, and opal minerals.
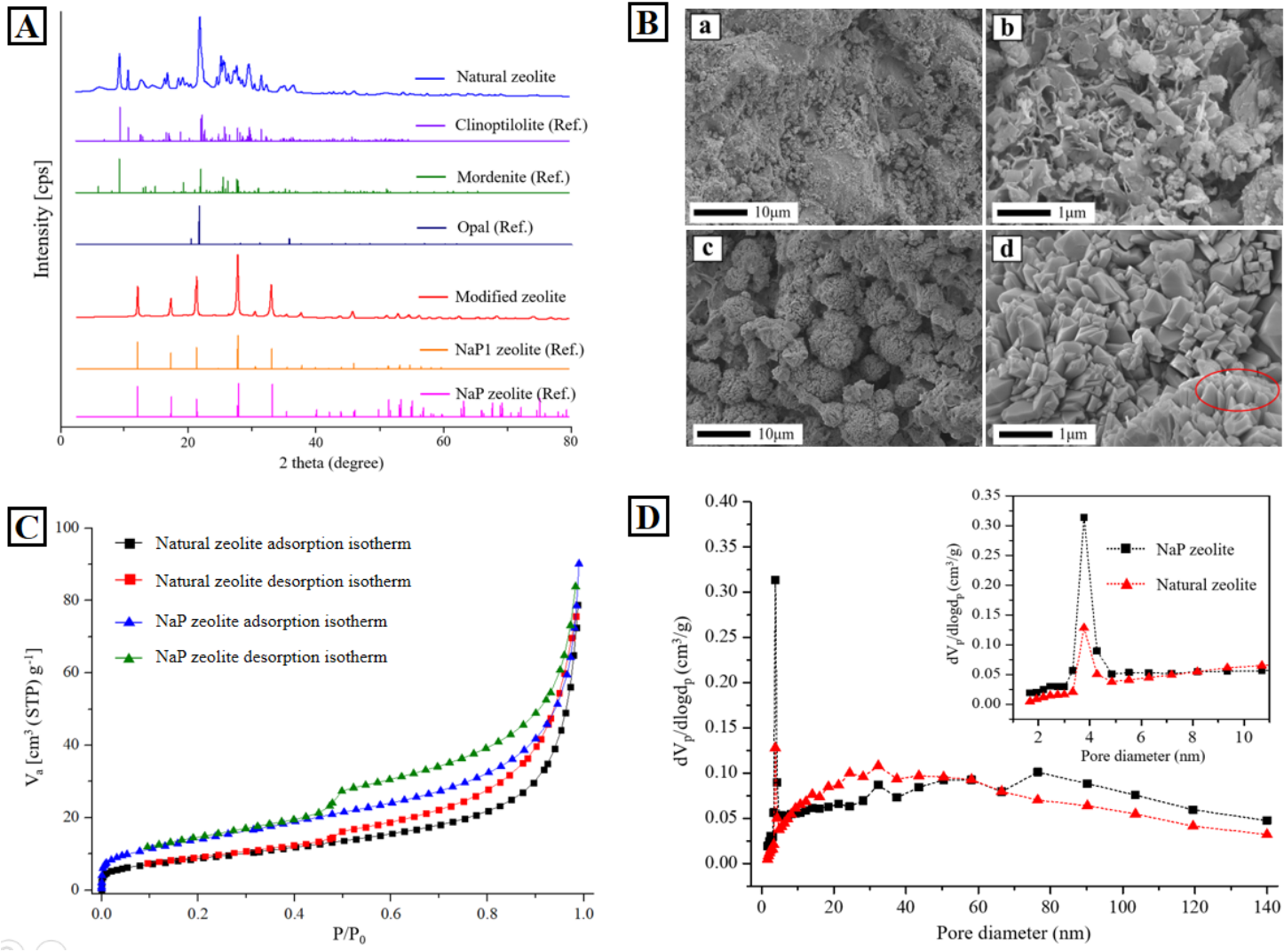

D

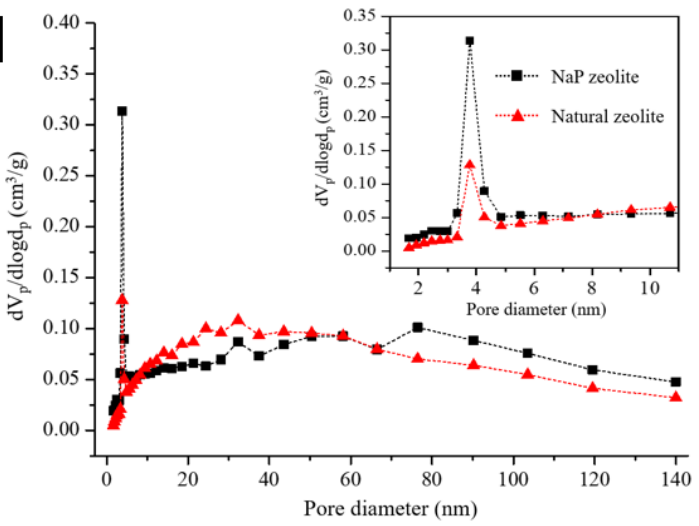

Figure 2. Characterization of granular-sized natural zeolite and NaP zeolite. (A): XRD patterns with known references; (B): SEM images of natural zeolite $(\mathbf{a}, \mathbf{b})$ and $\mathrm{NaP}$ zeolite $(\mathbf{c}, \mathbf{d})$ at different magnifications; $(\mathbf{C}): \mathrm{N}_{2}$ adsorption/desorption isotherms; and (D): BJH pore size distribution obtained from the desorption branch.

Nevertheless, compared with natural zeolite, our NaP zeolite reveals two remarkable characteristics within its chemical composition. The first is that the Si/Al ratio of our $\mathrm{NaP}$ zeolite decreased significantly. Second, in Table S2, as the Si/Al ratio of the NaP zeolite is approximately 1.75, it matches well with the chemical formula of common NaP1 zeolites, namely, $\mathrm{Na}_{6} \mathrm{Al}_{6} \mathrm{Si}_{10} \mathrm{O}_{32} \cdot 12 \mathrm{H}_{2} \mathrm{O}$ [24]. Here, the $\mathrm{Si} / \mathrm{Al}$ ratio of our $\mathrm{NaP}$ zeolite is about 2.5 times lower than that of natural zeolite. Another remarkable characteristic of the $\mathrm{NaP}$ zeolite is the significant increase in the weight percent of $\mathrm{Na}^{+}$and the slight decrease of $\mathrm{K}^{+}$. This is likely due to the $\mathrm{NaOH}$ solution used to synthesize the $\mathrm{NaP}$ zeolite, where $\mathrm{K}^{+}$ and $\mathrm{Na}^{+}$ions exchanged as additional $\mathrm{Na}^{+}$was introduced into the starting natural zeolite.

The corresponding SEM images showing the surface morphology of natural and $\mathrm{NaP}$ zeolites can be seen in Figure 2B. For natural zeolite, micro-particles are widely distributed, revealing the particles with irregular morphology (a in Figure 2B). Unlike natural zeolite, the $\mathrm{NaP}$ zeolite's micro-particles were found to form spherical clusters (c in Figure 2B) with variations in size generally ranging from 1 to $10 \mu \mathrm{m}$. By comparing a and c in Figure 2B, empty space is also more apparent on the surfaces of the NaP zeolites. This is because the micro-particles in natural zeolite agglomerate into spherical clusters, which likely results in the creation of empty space during the fabrication process of $\mathrm{NaP}$ zeolite. In addition, this kind of agglomeration phenomenon also increases the intercrystalline pores.

The resulting morphological surface analyses of both natural and NaP zeolites are shown in $b$ and $d$ of Figure 2B. It is clear from these figures that natural zeolite consists of very thin sheet-shaped nanostructures (b in Figure 2B), which are similar to those of the platelet-like shapes from opal minerals [25]. In contrast, the $\mathrm{NaP}$ zeolite consists mainly of bulkier nanostructures (c in Figure 2B). These nanostructures also have various shapes, 
including square bipyramids. Specifically, as shown in d of Figure 2B) with the red circle, these square bipyramidal crystals seem to confirm an orthorhombic geometry and are akin to gismondine-like structures. Generally, these structures are predominately found in low-silica grade NaP-type zeolites because, although they have different pore sizes, $\mathrm{NaP}$ zeolites have similar crystal frameworks to gismondine [26].

The elemental surface mapping of the natural and NaP zeolites was measured using SEM-EDX (Figure S3). In Figure S3a, the selected sample area of natural zeolite appears to have a high $\mathrm{Si} / \mathrm{Al}$ ratio, which matches well with the XRF data found for natural zeolite. Overall, elemental mapping also found $\mathrm{Na}, \mathrm{Al}, \mathrm{Si}$, and $\mathrm{O}$ to be distributed equally in the natural zeolite. For the $\mathrm{NaP}$ zeolite (Figure $\mathrm{S} 3 \mathrm{~b}$ ), a low $\mathrm{Si} / \mathrm{Al}$ ratio was observed at the surface, with large amounts of Na present. This result also corresponds well with the previous XRF data found for the $\mathrm{NaP}$ zeolite. Although the $\mathrm{NaP}$ zeolites were modified from natural zeolite, its complete elemental mapping still showed similar distributions for $\mathrm{Al}, \mathrm{Si}$, and $\mathrm{O}$ in comparison with $\mathrm{Na}$.

The specific BET surface area $\left(\mathrm{S}_{\mathrm{BET}}\right)$ was calculated using the BET methods, with the values of both granular- and powder-sized zeolites shown in Table S3. Here, we can see that the $\mathrm{NaP}$ zeolites had a specific surface area around three times higher than natural zeolite regardless of their sizes. Based on the fact that $\mathrm{NaP}$ zeolite has a lower $\mathrm{Si} / \mathrm{Al}$ ratio compared to natural zeolite, we considered that $\mathrm{Si}$ was dissolved by the $\mathrm{NaOH}$ solution and this created more empty pores in the zeolite structures. Therefore, this increase in pores has resulted in an increase in specific surface area, resulting in $\mathrm{NaP}$ zeolite having more adsorption sites than the natural zeolite.

In our BET analysis (Table S3), both granular- and powder-sized zeolite data were analyzed and results showed that there were no significant differences between them, in both cases of natural and $\mathrm{NaP}$ zeolites. This is mainly due to the high porosity of zeolites in general. In other words, even though granular zeolites have larger volumes compared with powdered zeolites, they still have the porous structures that allow the $\mathrm{NaOH}$ solution to penetrate further inside. This may also explain why the granular natural zeolite could be synthesized uniformly into $\mathrm{NaP}$ zeolite. During the transition phase, the surface areas exposed to the $\mathrm{NaOH}$ solution could be used to form spherical clusters that formed the $\mathrm{NaP}$ zeolite, as shown in c of Figure 2B. This means that the $\mathrm{NaOH}$ solution was able to successfully convert natural zeolite into $\mathrm{NaP}$ zeolite, but only through contact points on the zeolite surface. The NaP zeolite was also formed inside the granular zeolite, as the $\mathrm{NaOH}$ solution easily penetrated the pores of the natural zeolite and thus was able to react uniformly. In addition, through SEM image analysis, we also confirmed that during the $\mathrm{NaP}$ zeolite formation, micro-particles agglomerated into spherical clusters, which resulted in a large amount of empty space, thus increasing porosity. Indeed, both powdered and granular NaP zeolites had slightly higher total pore volumes of 0.1392 and $0.0990 \mathrm{~cm}^{3} / \mathrm{g}$, respectively, compared with those of the powdered and granular natural zeolites, measured as 0.1218 and $0.0765 \mathrm{~cm}^{3} / \mathrm{g}$, respectively (Table S3); the micropore volumes of powdered and granular NaP zeolite ( 0.0357 and $0.0214 \mathrm{~cm}^{3} / \mathrm{g}$, respectively) were also higher than those of powdered and granular natural zeolite $\left(0.0159\right.$ and $0.0156 \mathrm{~cm}^{3} / \mathrm{g}$, respectively).

The $\mathrm{N}_{2}$ adsorption-desorption isotherms can be seen in Figure $2 \mathrm{C}$. Here, both natural and NaP zeolites showed clear hysteresis loops, indicative of mesoporosity in both cases [27]. These hysteresis loops are similar to the H3 type in the IUPAC classification [28]. Compared with natural zeolite, the $\mathrm{NaP}$ zeolite showed a much larger hysteresis loop, likely indicative of much higher mesoporosity $(2-50 \mathrm{~nm})$. This mesoporosity was also well identified in $\mathrm{BJH}$ plot (Figure 2D). From the $\mathrm{BJH}$ plot, the NaP zeolites have more mesopores of 2 to $8 \mathrm{~nm}$ than the natural zeolites, especially at about $\sim 4 \mathrm{~nm}$. In contrast, natural zeolites have slightly more mesopores of 8 to $50 \mathrm{~nm}$ than the NaP zeolites. Compared to the results of Pankaj Sharma et al. [29], the size of the mesopores in our NaP zeolite was a bit smaller. 


\subsection{Mechanism of NaP Zeolite Formation}

To analyze the transformation process from natural zeolite to $\mathrm{NaP}$ zeolite, $\mathrm{XRD}$ patterns were measured over different reaction times with $3 \mathrm{M}$ of $\mathrm{NaOH}$ solution at $96^{\circ} \mathrm{C}$. The results of this analysis are shown in Figure 3, where 12 time intervals are shown depicting the initial natural zeolite phase all the way to the final $\mathrm{NaP}$ zeolite phase. Overall, until 6-h reaction time, the XRD peaks of the natural zeolite were shown to decrease gradually, whereas from 9 to $60 \mathrm{~h}$, the NaP zeolite peaks were found to gradually increase. We therefore defined this decrease as the "decrystallization phase" (up to 6-h reaction) and the increase in NaP zeolite peaks as the "recrystallization phase".
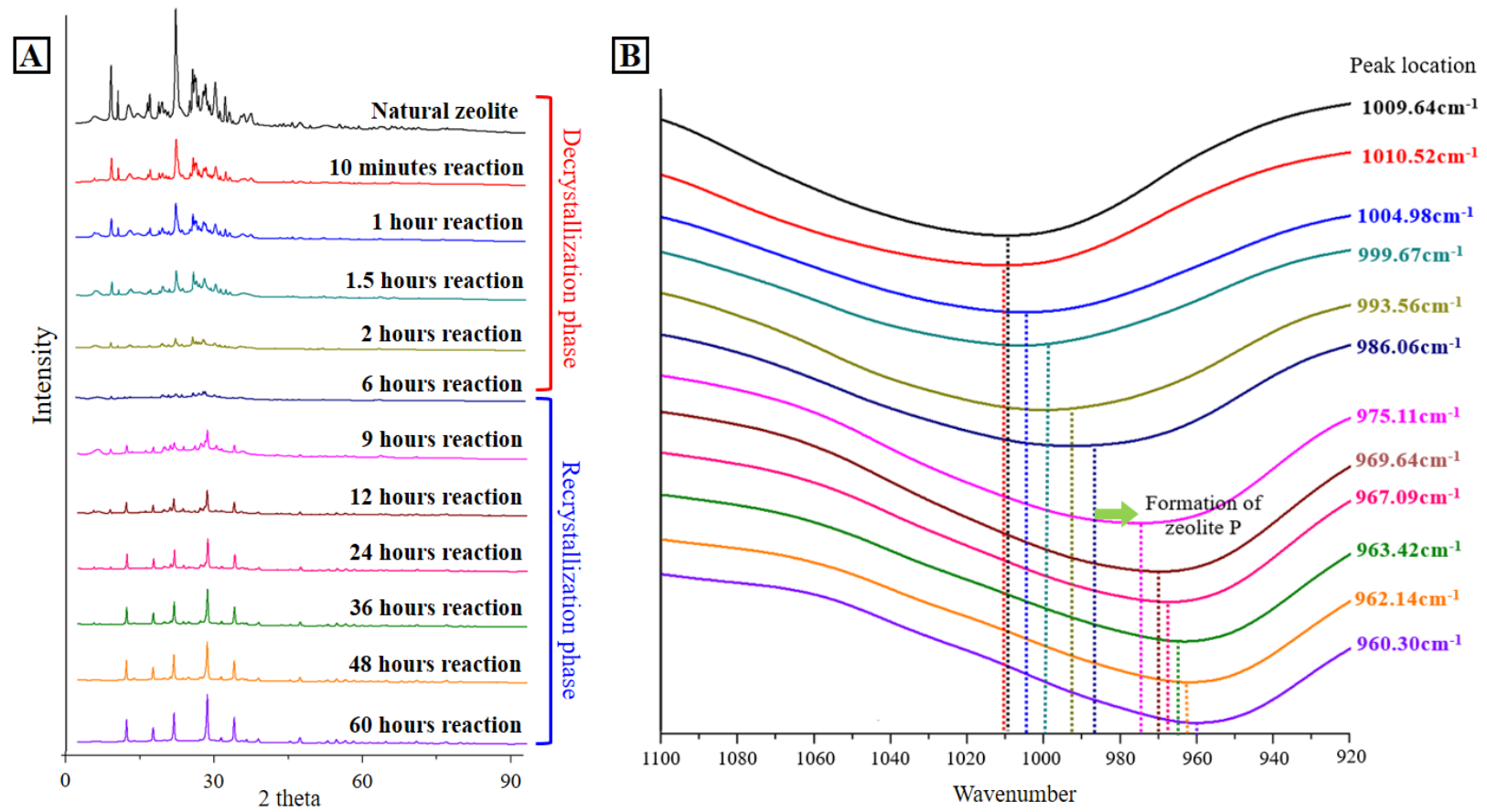

Figure 3. Zeolite phase transition analysis from natural zeolite to NaP zeolite by XRD pattern (A) and FT-IR peak (B) at different reaction.

It is clear that the peaks belonging to the natural zeolite began to decrease after $10 \mathrm{~min}$ of reaction time. At the 1.5-h mark, major peaks around $22^{\circ}-23^{\circ}$ were found to decrease rapidly. As mentioned earlier, this peak belongs to opal minerals and is known to dissolve well, even at $100{ }^{\circ} \mathrm{C}$ in $0.5 \mathrm{M}$ of NaOH solution [22]. Therefore, the reason for this rapid decrease is likely due to the opal minerals dissolving much faster than clinoptilolite or mordenite at $96{ }^{\circ} \mathrm{C}$ in $3 \mathrm{M} \mathrm{NaOH}$ solution. At the $9 \mathrm{~h}$ mark, XRD peaks of $\mathrm{NaP}$ zeolite were found, however, not only does the peak of the $\mathrm{NaP}$ zeolite appear clearly, but other residual peaks also appear. These residual peaks were found to be intermediate phases that formed prior to the formation of the $\mathrm{NaP}$ zeolite, although most of these disappeared after $12 \mathrm{~h}$ of reaction time. Distinct $\mathrm{NaP}$ zeolite peaks started to show after $24 \mathrm{~h}$ of reaction, and they gradually increased until at the $60 \mathrm{~h}$ mark.

The FT-IR spectra of zeolites with different reaction times are also shown in Figure 3. A strong absorption peak exists between $960 \mathrm{~cm}^{-1}$ and $1050 \mathrm{~cm}^{-1}$ which steadily shifts to the lower wavenumber as the reaction time increased; however, the absorption peak temporarily shifted to the higher wavenumber only at the $10 \mathrm{~min}$ point during the reaction (natural zeolite: $1009.60 \mathrm{~cm}^{-1}, 10 \mathrm{~min}$ reaction time: $1010.52 \mathrm{~cm}^{-1}$ ). In addition, it showed a particularly large shift as the reaction time increased from $6 \mathrm{~h}$ to $9 \mathrm{~h}$. This is also consistent with the distinction time between the decrystallization and the recrystallization phases as seen in the previous XRD results (Figure 3).

As mentioned before, we found the $\mathrm{Si}-\mathrm{O}$ bond and the $\mathrm{Si}-\mathrm{O}-\mathrm{Si}$ bond located around $1060-1080 \mathrm{~cm}^{-1}$ [30], and the $\mathrm{Si}-\mathrm{OH}$ bond at $960 \mathrm{~cm}^{-1}$ [31] were primarily the strongest 
absorption peaks. In literature, $\mathrm{Si}-\mathrm{O}$ and $\mathrm{Si}-\mathrm{O}-\mathrm{Si}$ bonds on silica surfaces are generally converted into $\mathrm{Si}-\mathrm{OH}$ bonds during the $\mathrm{Si}$ dissolution process, particularly under high $\mathrm{pH}$ conditions [32]. Therefore, if the IR peaks shift based on the desilication mechanism, we can then estimate that the typical $\mathrm{Si}-\mathrm{O}$ and $\mathrm{Si}-\mathrm{O}-\mathrm{Si}$ bonds (around $1060-1080 \mathrm{~cm}^{-1}$ ) from the original natural zeolite have all been converted into $\mathrm{Si}-\mathrm{OH}$ bonds $\left(\right.$ at $960 \mathrm{~cm}^{-1}$ ), where the absorption peak shifts to a lower wavenumber. Furthermore, as the reaction time increased, the absorption peak was found to be stronger because more $\mathrm{Si}-\mathrm{OH}$ bonds were generated over time.

However, the desilication mechanism does not clearly explain the temporary shift to the higher wavenumber at the $10 \mathrm{~min}$ reaction time. Instead, this temporary peak-shift can be interpreted with the zeolite mass increase due to the sudden $\mathrm{Na}^{+}$sorption (Figure S4). At the 10 min point of the reaction, we can see that the total mass of zeolite temporarily increased (Figure S4a), and the amount of $\mathrm{Na}^{+}$also rapidly increased (Figure S4b). Rimsza et al. [33] described this mechanism, as when the surface of the silica material is first deprotonated by a high concentration of $\mathrm{OH}^{-}$(at high $\mathrm{pH}$ ) and then $\mathrm{Na}^{+}$ion existing mainly adjacent to the silica surface can adsorb on the negatively charged surface hydroxyl site, which causes the peak shift at the $10 \mathrm{~min}$ reaction point due to the reduction of $\mathrm{Si}-\mathrm{OH}$ bonds.

\subsection{Visualization of NaP Zeolite Formation Process}

We investigated the surface morphological changes that occurred during the conversion from natural zeolite to $\mathrm{NaP}$ zeolite at three different SEM magnifications. At the lower magnification (Figure S5), there were no large differences between the original natural zeolite's surface (a in Figure 2B) and that at the 10 min point of the reaction (Figure S5a). However, there were larger pores on the surface of the zeolite found at the $1 \mathrm{~h}$ point of the reaction (Figure S5b). Again, this was similar to the morphology observed at the $2 \mathrm{~h}$ point of the reaction (Figure S5c). At the $9 \mathrm{~h}$ point of the reaction (Figure S5d), those micrometersized pores that were created by the $\mathrm{NaOH}$ were connected to each other, resulting in channels of larger pores appearing on the zeolite surface. The formation of the spherical clusters in the NaP zeolite was observed at the $24 \mathrm{~h}$ point of the reaction (Figure S5e), and after $48 \mathrm{~h}$ of the reaction (Figure S5f), even larger amounts of spherical clusters were formed (Figure S5e).

At the higher magnification (Figure 4), the entire top-down synthesis process from the natural zeolite to the $\mathrm{NaP}$ zeolite can be identified with more clear surface morphological changes. We already saw that the initial natural zeolite is composed of a rough surface with no regularities or clear features (Figure 4a). Moreover, the surface changed after 10 min of reaction time (Figure $4 \mathrm{~b}$ ), beginning to smooth over likely due to an initial uptake of $\mathrm{Na}^{+}$. Over time, the $\mathrm{NaOH}$ solution dissolved more $\mathrm{Si}$, resulting in macro-cracks (Figure 4c,d), which divided the zeolite into several small masses (Figure 4e). After $24 \mathrm{~h}$ of the reaction (Figure 4f), these small masses were then converted into spherical-shape $\mathrm{NaP}$ zeolite clusters. By comparing the structure at $24 \mathrm{~h}$ (Figure $4 \mathrm{f}$ ) with that at $60 \mathrm{~h}$ (Figure $4 \mathrm{~h}$ ), the spherical clusters at $24 \mathrm{~h}$ (Figure $4 \mathrm{f})$ grew to be larger in size $(\sim 10 \mu \mathrm{m})$ and connected, while the spherical clusters at $60 \mathrm{~h}$ (Figure $4 \mathrm{~h}$ ) were found to pose clear boundaries with varying sizes from 3 to $10 \mu \mathrm{m}$. This phenomenon is related to the residual cracks (Figure $4 \mathrm{~g}$, red box) seen at $48 \mathrm{~h}$. Based on these cracks, large spherical $\mathrm{NaP}$ zeolite clusters were separated into several smaller clusters, as shown in Figure $4 \mathrm{~h}$.

Besides, the nanostructure of the zeolites was also changed as a function of reaction time. The original crystalline nanostructures of the natural zeolite (Figure S6a) became amorphous-like porous structures (Figure S6b-d), because of the considerable Si dissolution. At the $9 \mathrm{~h}$ point of the reaction (Figure S6e), nanostructures started to form again in tandem with spherical clusters. This result correlates well with the previous XRD (Figure 3) and XRF (Figure S4) results, which indicate that recrystallization begins from $9 \mathrm{~h}$ reaction. After $24 \mathrm{~h}$ of the reaction (Figure S6f), some cactus-shaped micrometer-sized crystallines $(>\sim 1 \mu \mathrm{m})$ started to show up. At $48 \mathrm{~h}$ of the reaction, they changed back to diamond- 
shaped nanometer-sized crystallines with a size of 200-300 nm (Figure S6g), and these diamond-shaped structures were also clearly shown at the $60 \mathrm{~h}$ point of the reaction time (Figure S6h). Diamond-shaped NaP zeolites have a lower Si/Al ratio than the cactusshaped $\mathrm{NaP}$ zeolites [18]. Therefore, it is interpreted that the crystal structure of our cactus-shaped NaP zeolites (Figure S7a,b) have changed to diamond shape (Figure S7c,d) through an additional desilication process.
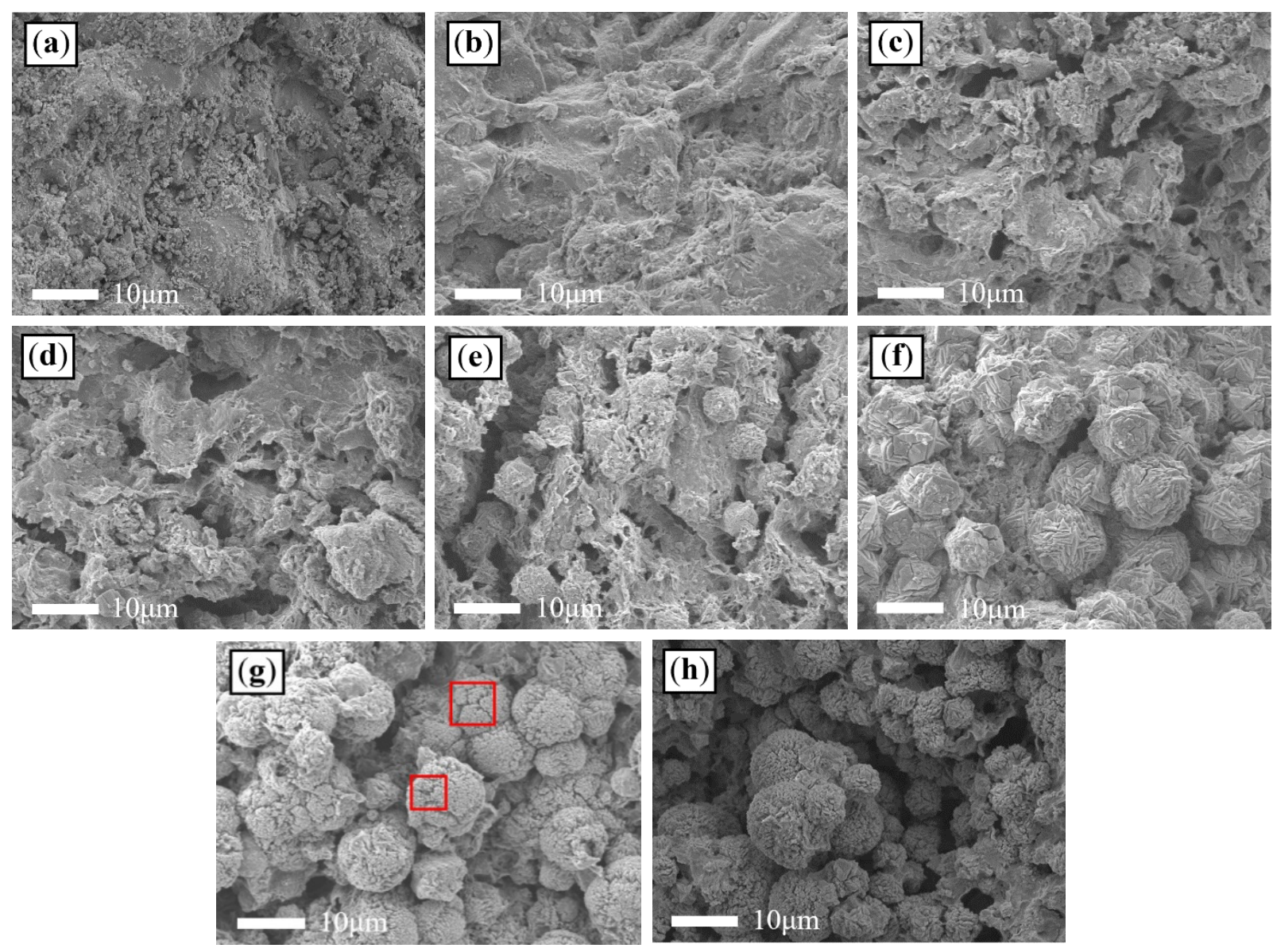

Figure 4. SEM images of natural and NaP zeolites. Morphology variation with different reaction times; (a) natural zeolite, (b) $10 \mathrm{~min},(\mathbf{c}) 1 \mathrm{~h},(\mathbf{d}) 2 \mathrm{~h},(\mathbf{e}) 9 \mathrm{~h},(\mathbf{f}) 24 \mathrm{~h},(\mathrm{~g}) 48 \mathrm{~h}$, and (h) $60 \mathrm{~h}$.

Through these results, the concepts of decrystallization and recrystallization were further visualized with these time-dependent SEM analyses, and it was also possible to observe the crystal structural changes of the spherical clusters, where the initial cactuslike shapes transformed into diamond-like shapes as the desilication reaction progressed (Figure S8).

\subsection{Removal of $\mathrm{Cs}^{+}, \mathrm{Ni}^{2+}$, and $\mathrm{Sr}^{2+}$ Using the Natural and $\mathrm{NaP}$ Zeolites}

As shown in Table 1, the $\mathrm{R}^{2}$ value of the pseudo-second-order kinetic model was found to be higher than that of the pseudo-first-order kinetic model in both cases of natural zeolite and $\mathrm{NaP}$ zeolite. Also, the experimental $\mathrm{Q}_{\mathrm{e}}$ values were highly matched with the calculated Qe value using the pseudo-second-order kinetic model. Kinetic experiments (Figure 5) have shown that the time to reach equilibrium depends on the type of target radionuclides. In our experiments, Cs reached equilibrium within $12 \mathrm{~h}$ for both zeolites, but $\mathrm{Sr}$ and $\mathrm{Ni}$ were not found to reach equilibrium until $24 \mathrm{~h}$ later. Hitoshi Mimura et al. [11] showed similar results indicating that the $\mathrm{Cs}$ removal rate of both natural zeolite and $\mathrm{NaP}$ zeolite was faster than the removal rate of Sr. 
Table 1. Results of the pseudo-first-order and pseudo-second-order adsorption kinetics models.

\begin{tabular}{|c|c|c|c|c|c|c|c|}
\hline \multirow{2}{*}{ Type } & \multicolumn{4}{|c|}{ Pseudo-First-Order } & \multicolumn{3}{|c|}{ Pseudo-Second-Order } \\
\hline & $Q_{e, \exp }(\mathrm{mg} / \mathrm{g})$ & $k_{1}(1 / h)$ & $\mathrm{Q}_{\mathrm{e}, \mathrm{cal}}(\mathrm{mg} / \mathrm{g})$ & $\mathbf{R}^{2}$ & $k_{2}(g / m g \cdot h)$ & $\mathrm{Q}_{\mathrm{e}, \mathrm{cal}}(\mathrm{mg} / \mathrm{g})$ & $\mathbf{R}^{2}$ \\
\hline Natural zeolite-Cs & 49.51 & 0.2431 & 0.1094 & 0.9024 & 0.2721 & 49.50 & 0.9999 \\
\hline Natural zeolite-Sr & 13.22 & 0.0298 & 0.2811 & 0.0133 & 0.0562 & 13.37 & 0.9996 \\
\hline Natural zeolite- $-\mathrm{Ni}$ & 5.21 & 0.1774 & 0.7238 & 0.8881 & 0.1126 & 5.27 & 0.9997 \\
\hline $\mathrm{NaP}$ zeolite-Cs & 51.52 & 0.1220 & 0.0179 & 0.1522 & 0.3421 & 51.55 & 0.9999 \\
\hline $\mathrm{NaP}$ zeolite-Sr & 27.93 & 0.1934 & 0.2206 & 0.9068 & 0.1677 & 28.01 & 0.9999 \\
\hline $\mathrm{NaP}$ zeolite- $-\mathrm{Ni}$ & 24.51 & 0.2044 & 0.3209 & 0.9697 & 0.1288 & 24.63 & 0.9999 \\
\hline
\end{tabular}
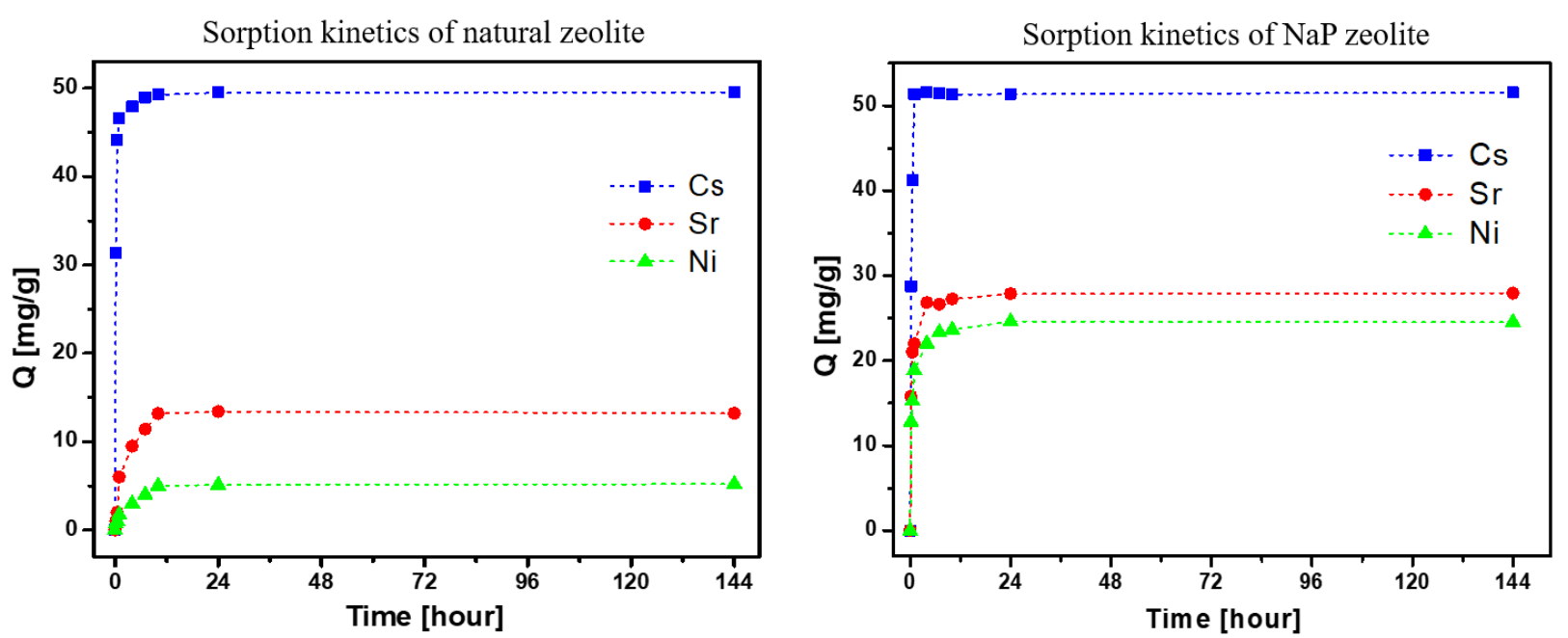

Figure 5. Adsorption kinetics for the removal of $\mathrm{Cs}, \mathrm{Sr}$, and $\mathrm{Ni}$ by natural zeolite and $\mathrm{NaP}$ zeolite.

The adsorption isotherms for the removal of $\mathrm{Cs}, \mathrm{Sr}$, and $\mathrm{Ni}$ on natural zeolite and $\mathrm{NaP}$ zeolite are shown in Figure 6, and each fitting parameter is shown in Table 2. As shown in Table 3, the $\mathrm{R}^{2}$ value of the Langmuir isotherm is higher than that of the Freundlich isotherm. After the phase transition from natural zeolite to $\mathrm{NaP}$ zeolite, it was shown that the maximum removal capacity $\left(Q_{\max }\right)$ of $C$ s was almost the same, but the $Q_{\max }$ values of $\mathrm{Sr}$ and $\mathrm{Ni}$ were all increased. The cation exchange capacity results in Table 3 are also consistent with our isotherm data. The total CEC value of $\mathrm{NaP}$ zeolite was about 2.5 times higher than that of natural zeolite. Because the $\mathrm{N}_{2}$ gas cannot completely represent the adsorption/desorption accessibility of the cations ( $\mathrm{Cs}, \mathrm{Sr}$, and $\mathrm{Ni}$ ), the increase of the cation removal efficiency cannot be explained only with the increase of the specific surface area, but can be explained with the increase of CEC value.

To compare the removal efficiency of different sizes of $\mathrm{NaP}$ zeolite, batch sorption experiments were conducted (Figure S9). In Figure S9, granular-sized NaP zeolite showed an almost similar removal efficiency to the powder-sized NaP zeolite. Through these results, granular-sized $\mathrm{NaP}$ zeolite is expected to show a high removal efficiency, as much as powder-sized NaP zeolite. Therefore, additional batch sorption tests were conducted with these granular-sized $\mathrm{NaP}$ zeolites, under the conditions of Hanbit groundwater containing $\mathrm{Cs}^{+}, \mathrm{Sr}^{2+}$, and $\mathrm{Ni}^{2+}$ (each 100, $10 \mathrm{ppm}$ ) simultaneously. As a result, in both cases of 100 and 10 ppm conditions, the removal efficiency of each radionuclide reached at least $98 \%$ (Figure 7A). Nowadays in the industrial field, pelletized powder sorbents are widely used, however, the above results show the potential of replacing pellet zeolites with granular-sized $\mathrm{NaP}$ zeolites. 
Table 2. Fitting parameters of Langmuir and Freundlich adsorption isotherms.

\begin{tabular}{|c|c|c|c|c|c|c|}
\hline \multirow{2}{*}{ Type } & \multicolumn{3}{|c|}{ Langmuir } & \multicolumn{3}{|c|}{ Freundlich } \\
\hline & $\mathrm{Q}_{\max }(\mathrm{mg} / \mathrm{g})$ & $\mathrm{K}_{\mathrm{L}}(\mathrm{L} / \mathrm{mg})$ & $\mathrm{R}^{2}$ & $1 / \mathrm{n}$ & $\mathrm{K}_{\mathrm{F}}(\mathrm{L} / \mathrm{mg})$ & $\mathbf{R}^{2}$ \\
\hline Natural zeolite-Cs & 40.00 & 1.968 & 0.9543 & 0.1909 & 18.58 & 0.9095 \\
\hline Natural zeolite-Sr & 12.75 & 4.962 & 0.9606 & 0.2089 & 7.360 & 0.8865 \\
\hline Natural zeolite-Ni & 6.09 & 7.139 & 0.9832 & 0.1864 & 2.732 & 0.6386 \\
\hline $\mathrm{NaP}$ zeolite-Cs & 58.82 & 0.178 & 0.9842 & 0.2766 & 16.19 & 0.7329 \\
\hline $\mathrm{NaP}$ zeolite- $\mathrm{Sr}$ & 25.32 & 1.716 & 0.9329 & 0.1537 & 11.26 & 0.9235 \\
\hline $\mathrm{NaP}$ zeolite- $\mathrm{Ni}$ & 24.57 & 7.017 & 0.9994 & 0.0933 & 15.56 & 0.8027 \\
\hline
\end{tabular}
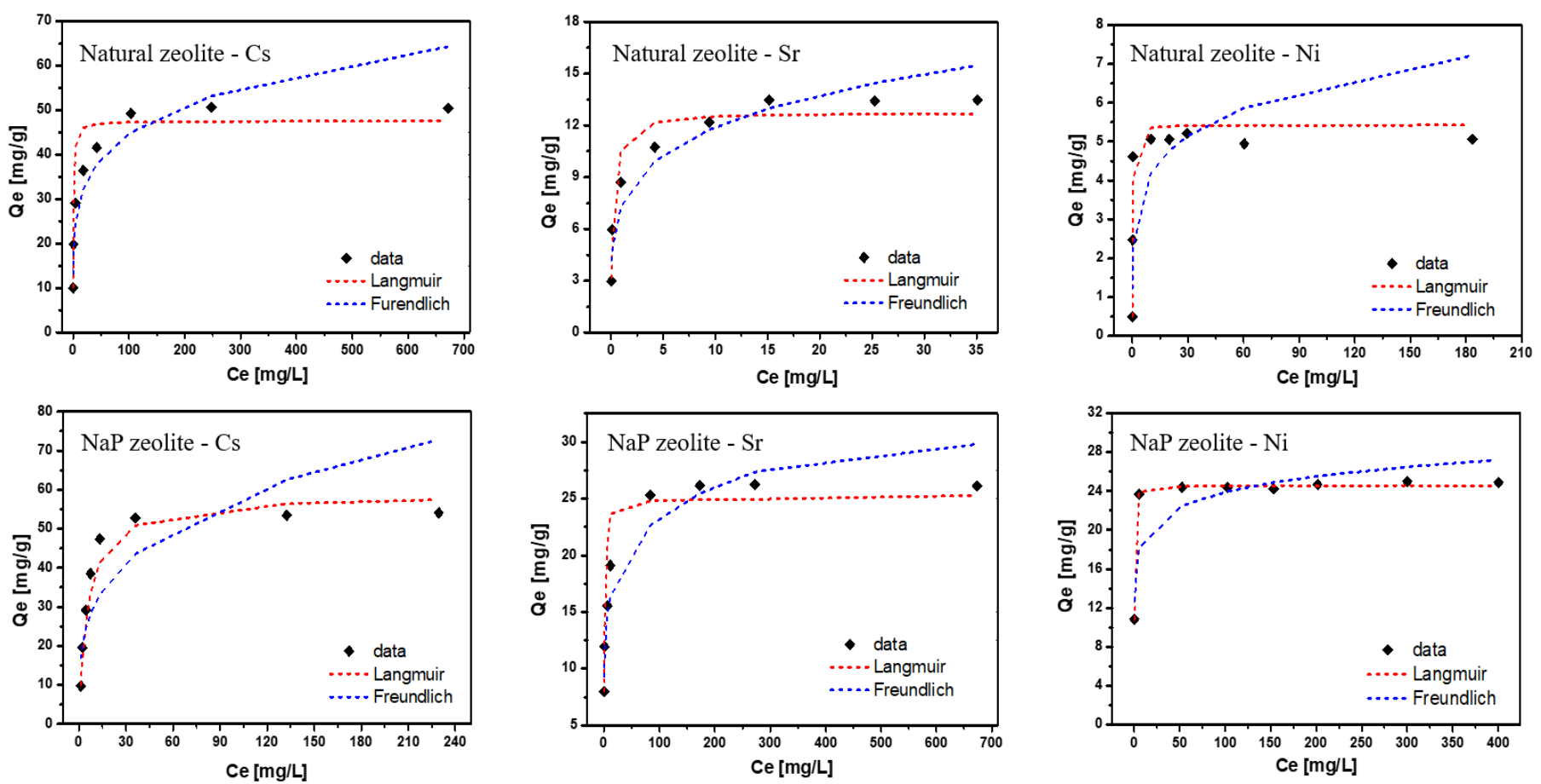

Figure 6. Adsorption isotherms for the removal of $\mathrm{Cs}, \mathrm{Sr}$, $\mathrm{Ni}$ on natural zeolite and $\mathrm{NaP}$ zeolite. (solid to solution ratio: $1 \mathrm{~g} / 100 \mathrm{~mL}$, batch sorption reaction time for equilibrium: 7 days).
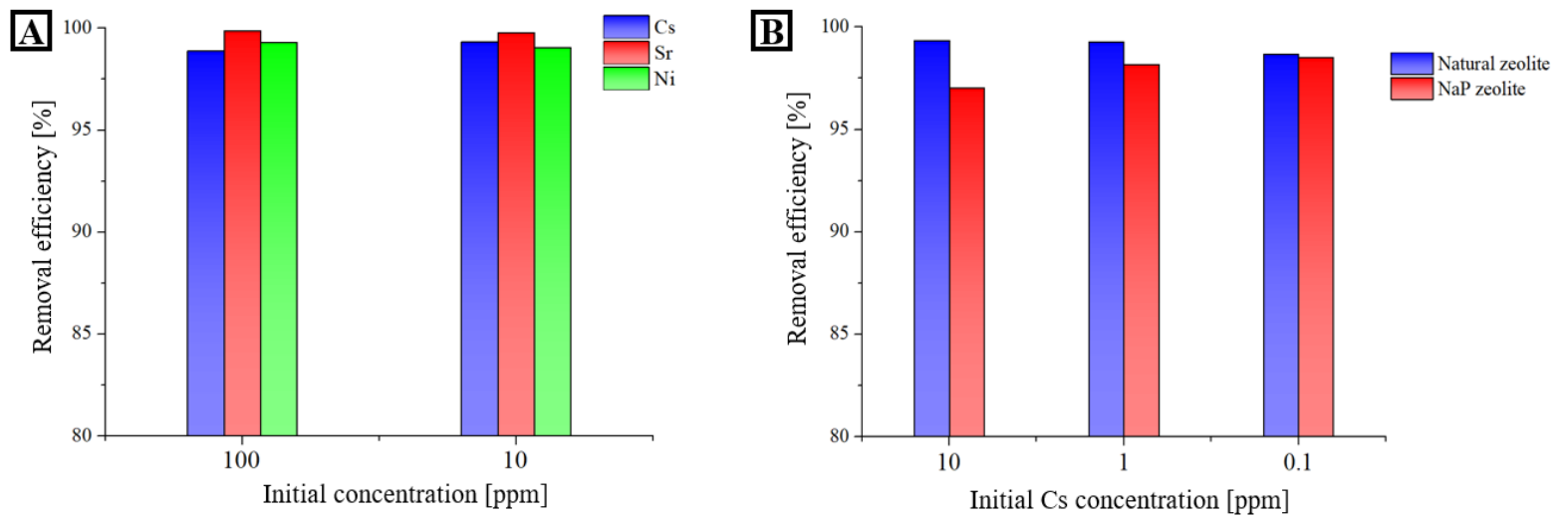

Figure 7. Batch sorption results of zeolites with the solid to solution ratio of $100 \mathrm{~mL} / \mathrm{g}$. (A): removal efficiency of granularsized $\mathrm{NaP}$ zeolite in Hanbit groundwater with 100 and $10 \mathrm{ppm}$ of $\mathrm{Cs}^{+}, \mathrm{Sr}^{2+}$, and $\mathrm{Ni}^{2+}$. (B): Batch sorption data for the removal of $\mathrm{Cs}^{+}$with granular-sized natural zeolite and $\mathrm{NaP}$ zeolite at various concentrations in groundwater collected around the Hanbit NPP site. (Error bar was omitted because of too small range). 
Table 3. Cation exchange capacity of natural zeolite and $\mathrm{NaP}$ zeolite.

\begin{tabular}{cccccc}
\hline \multirow{2}{*}{ Type } & $\mathbf{C a}$ & $\mathbf{N a}$ & $\mathbf{K}$ & $\mathbf{M g}$ & Total CEC \\
\cline { 2 - 6 } & \multicolumn{5}{c}{$\mathbf{c m o l} / \mathbf{k g}$} \\
\hline Natural zeolite & 61.90 & 47.63 & 5.94 & 3.72 & 119.19 \\
\hline NaP zeolite & 105.63 & 174.32 & 2.09 & 28.85 & 310.89 \\
\hline
\end{tabular}

Since the potential concentration of radioactive ${ }^{137}$ Cs leaking into the environment is normally less than $0.1 \mathrm{ppm}$ [34], we additionally conducted low-concentration $\mathrm{Cs}^{+}$batch sorption tests $(0.1 \mathrm{ppm}$ and $1 \mathrm{ppm})$ with Hanbit groundwater. Although the $\mathrm{NaP}$ zeolite showed slightly lower $\mathrm{Cs}^{+}$-removal efficiency than the natural zeolite, both natural and $\mathrm{NaP}$ zeolites still showed a $\mathrm{Cs}^{+}$removal efficiency above $98 \%$ (Figure 7B). Furthermore, when the initial $\mathrm{Cs}^{+}$concentration was $0.1 \mathrm{ppm}$, the removal efficiency of the natural zeolite reached about $99.3 \%$ and the NaP zeolite reached about $98.5 \%$ (Figure $7 \mathrm{~B}$ ), which is not significantly different. Although the $\mathrm{Cs}^{+}$removal efficiency of the natural and $\mathrm{NaP}$ zeolite was similar, the removal efficiencies for $\mathrm{Sr}^{2+}$ and $\mathrm{Ni}^{2+}$ were found to be much higher for the $\mathrm{NaP}$ zeolite compared with those for the natural zeolite and thus $\mathrm{NaP}$ zeolite can be successfully applied to treat mixed radionuclides (i.e., ${ }^{137} \mathrm{Cs},{ }^{90} \mathrm{Sr}$, and ${ }^{63} \mathrm{Ni}$ ) in radioactive waste solutions.

\section{Conclusions}

In this study, $\mathrm{NaP}$ zeolite was synthesized from Korean natural zeolite using the 'top-down approach' of hydrothermal synthesis. Below are the final conclusions.

(1) NaP zeolite was synthesized from natural zeolite, mainly consisting of clinoptilolite and mordenite. The NaP zeolite showed three times higher specific surface area and had a smaller pore size distribution than the original natural zeolite.

(2) The synthesis process was observed with time-dependent XRD, FT-IR, XRF, and SEM analysis. The desilication is the main mechanism of phase transition, and the whole synthesis process consists of decrystallization followed by a recrystallization phase.

(3) The maximum sorption capacity of natural zeolite and NaP zeolite was determined and showed that both zeolites fit well with Langmuir isotherms. The Cs removal efficiency of natural zeolite and $\mathrm{NaP}$ zeolite was not much different, however, for $\mathrm{Sr}$ and $\mathrm{Ni}$ the removal efficiency of $\mathrm{NaP}$ zeolite is much higher than the natural zeolite, showing the high applicability of $\mathrm{NaP}$ zeolite.

Supplementary Materials: The following are available online at https:/ / www.mdpi.com/2075-1 63X/11/3/252/s1. Figure S1: The location of a natural Korean zeolite-mining site (left) where the natural zeolite ore sample (right) was collected; Figure S2: The "top-down" synthesis approach to produce granular-sized zeolites; Figure S3: Elemental mapping of natural zeolite (a) and NaP zeolite (b) with SEM-EDX analysis; Figure S4: Mass variation (a) and composition variation (b) of zeolite with different reaction times; Figure S5: SEM images showing morphological changes at different reaction times; (a) 10 minutes, (b) 1 h, (c) 2 h, (d) 9 h, (e), 24 h, (f) 48 h; Figure S6: SEM images showing morphological changes at different reaction times; (a) Natural zeolite, (b) 10 minutes, (c) $1 \mathrm{~h}$, (d) 2 h, (e) 9 h, (f) 24 h, (g) 48 h, (h) 60 h; Figure S7: SEM images of two different-sized NaP; Figure S8: Morphological transition of the $\mathrm{NaP}$ zeolite with different $\mathrm{Si} / \mathrm{Al}$ ratios; Figure S9: Batch sorption measurements for the removal of Cs at various concentrations in groundwater collected around the Hanbit NPP site; Table S1: Composition of Hanbit groundwater; Table S2: Chemical compositions of granular-sized natural and NaP zeolites expressed in wt.\%; Table S3: Textural parameters of natural and $\mathrm{NaP}$ zeolites.

Author Contributions: Conceptualization: S.H.; Methodology: S.H.; Writing original draft: S.H. Investigation: S.H. Visualization: S.H. Supervisions: W.U. Writing review \& editing: W.U.; Project administration: W.U. Both authors have read and agreed to the published version of the manuscript. 
Funding: This research was supported by the Korea Hydro \& Nuclear Power company through the project "Nuclear Innovation Center for Haeoleum Alliance" and funding provided by the National Research Foundation of Korea funded by the Ministry of Education (NRF-2017M2B2B1072374).

Data Availability Statement: Not applicable.

Acknowledgments: Special thanks to Bhupendra Kumar Singh with analysis of BJH data.

Conflicts of Interest: The authors declare no conflict of interest.

\section{References}

1. Steinhauser, G.; Brandl, A.; Johnson, T.E. Comparison of the Chernobyl and Fukushima nuclear accidents: A review of the environmental impacts. Sci. Total Environ. 2014, 800-817. [CrossRef]

2. Zhu, Y.; Smolders, E. Plant uptake of radiocaesium: A review of mechanisms, regulation and application. J. Exp. Bot. 2000, 51, 1635-1645. [CrossRef] [PubMed]

3. Mähler, J.; Persson, I. A Study of the Hydration of the Alkali Metal Ions in Aqueous Solution. Inorg. Chem. 2011, 51, 425-438. [CrossRef]

4. Carboneau, M.L.; Adams, J.P. National Low-Level Waste Management Program Radionuclide Report Series. Volume 10, Nickel-63, DOE/LLW-126; Idaho National Engineering Laboratory: Idaho Falls, ID, USA, 1995.

5. Hamed, M.M.; Ali, M.; Holiel, M. Preparation of activated carbon from doum stone and its application on adsorption of ${ }^{60} \mathrm{Co}$ and ${ }^{152+154} \mathrm{Eu}$ : Equilibrium, kinetic and thermodynamic studies. J. Environ. Radioact. 2016, 164, 113-124. [CrossRef] [PubMed]

6. Loos-Neskovic, C.; Ayrault, S.; Badillo, V.; Jiménez, B.; Garnier, E.; Fedoroff, M.; Jones, D.; Merinov, B. Structure of copperpotassium hexacyanoferrate (II) and sorption mechanisms of cesium. J. Solid State Chem. 2004, 177, 1817-1828. [CrossRef]

7. Romanchuk, A.Y.; Kuzenkova, A.S.; Slesarev, A.S.; Tour, J.M.; Kalmykov, S.N. Cs(I) and Sr(II) Sorption onto Graphene Oxide. Solvent Extr. Ion Exch. 2016, 34, 594-602. [CrossRef]

8. Khan, S.A. Sorption of the long-lived radionuclides cesium-134, strontium-85 and cobalt-60 on bentonite. J. Radioanal. Nucl. Chem. 2003, 258, 3-6. [CrossRef]

9. Munthali, M.W.; Johan, E.; Aono, H.; Matsue, N. Cs ${ }^{+}$and $\mathrm{Sr}^{2+}$ adsorption selectivity of zeolites in relation to radioactive decontamination. J. Asian Ceram. Soc. 2015, 3, 245-250. [CrossRef]

10. Ivanova, I.I.; Knyazeva, E.E. Micro-mesoporous materials obtained by zeoliterecrystallization: Synthesis, characterization and catalytic applications. Chem. Soc. Rev. 2013, 42, 3671-3688. [CrossRef]

11. Mimura, H.; Akiba, K. Adsorption Behavior of Cesium and Strontium on Synthetic Zeolite P. J. Nucl. Sci. Technol. 1993, 30, 436-443. [CrossRef]

12. Kang, S.-J.; Egashira, K. Modification of different grades of Korean natural zeolites for increasing cation exchange capacity. Appl. Clay Sci. 1997, 12, 131-144. [CrossRef]

13. Johan, E.; Yamada, T.; Munthali, M.W.; Kabwadza-Corner, P.; Aono, H.; Matsue, N. Natural Zeolites as Potential Materials for Decontamination of Radioactive Cesium. Procedia Environ. Sci. 2015, 28, 52-56. [CrossRef]

14. Smičiklas, I.; Dimovic, S.; Plecas, I. Removal of $\mathrm{Cs}^{1+}, \mathrm{Sr}^{2+}$ and $\mathrm{Co}^{2+}$ from aqueous solutions by adsorption on natural clinoptilolite. Appl. Clay Sci. 2007, 35, 139-144. [CrossRef]

15. Wang, X.-S.; Huang, J.; Hu, H.-Q.; Wang, J.; Qin, Y. Determination of kinetic and equilibrium parameters of the batch adsorption of $\mathrm{Ni}$ (II) from aqueous solutions by Na-mordenite. J. Hazard. Mater. 2007, 142, 468-476. [CrossRef] [PubMed]

16. Argun, M.E. Use of clinoptilolite for the removal of nickel ions from water: Kinetics and thermodynamics. J. Hazard. Mater. 2008, 150, 587-595. [CrossRef]

17. Ambrozova, P.; Kynicky, J.; Urubek, T.; Nguyen, V.D. Synthesis and Modification of Clinoptilolite. Molecules 2017, $22,1107$. [CrossRef]

18. Huo, Z.; Xu, X.; Lü, Z.; Song, J.; He, M.; Li, Z.; Wang, Q.; Yan, L. Synthesis of zeolite NaP with controllable morphologies. Microporous Mesoporous Mater. 2012, 158, 137-140. [CrossRef]

19. Çelik, K.M.; Karakaya, N.; Bakır, S. Some properties and potential applications of the Na- and Ca-bentonites of ordu (N.E. Turkey). Appl. Clay Sci. 2011, 54, 159-165. [CrossRef]

20. Bayram, H.; Önal, M.; Yılmaz, H.; Sarıkaya, Y. Thermal analysis of a white calcium bentonite. J. Therm. Anal. Calorim. 2010, 101, 873-879. [CrossRef]

21. Bowers, T.S.; Burns, R.G. Activity diagrams for clinoptilolite; susceptibility of this zeolite to further diagenetic reactions. Am. Miner. 1990, 75, 601-619. Available online: https://pubs.geoscienceworld.org/msa/ammin/article-abstract/75/5-6/601/42378 (accessed on 26 January 2021).

22. Hillier, S.; Lumsdon, D.G. Distinguishing opaline silica from cristobalite in bentonites: A practical procedure and perspective based on $\mathrm{NaOH}$ dissolution. Clay Miner. 2008, 43, 477-486. [CrossRef]

23. Tanaka, H.; Yamasaki, N.; Muratani, M.; Hino, R. Structure and formation process of (K,Na)-clinoptilolite. Mater. Res. Bull. 2003, 38, 713-722. [CrossRef]

24. Ali, I.O.; El-Sheikh, S.M.; Salama, T.M.; Bakr, M.F.; Fodial, M.H. Controllable synthesis of NaP zeolite and its application in calcium adsorption. Sci. China Mater. 2015, 58, 621-633. [CrossRef] 
25. Lynne, B.Y.; Campbell, K.A. Morphologic and Mineralogic Transitions From Opal-A to Opal-CT in Low-Temperature Siliceous Sinter Diagenesis, Taupo Volcanic Zone, New Zealand. J. Sediment. Res. 2004, 74, 561-579. [CrossRef]

26. Albert, B.; Cheetham, A.; Stuart, J.; Adams, C. Investigations on P zeolites: Synthesis, characterisation, and structure of highly crystalline low-silica NaP. Microporous Mesoporous Mater. 1998, 21, 133-142. [CrossRef]

27. Li, L.; Cui, X.; Li, J.; Wang, J. Synthesis of SAPO-34/ZSM-5 Composite and Its Catalytic Performance in the Conversion of Methanol to Hydrocarbonsc. J. Braz. Chem. Soc. 2014, 26, 290-296. [CrossRef]

28. Donohue, M.; Aranovich, G. Classification of Gibbs adsorption isotherms. Adv. Colloid Interface Sci. 1998, 137-152. [CrossRef]

29. Sharma, P.; Song, J.-S.; Han, M.H.; Cho, C.-H. GIS-NaP1 zeolite microspheres as potential water adsorption material: Influence of initial silica concentration on adsorptive and physical/topological properties. Sci. Rep. 2016, 6, 22734. [CrossRef]

30. Yu, K.M.K.; Thompsett, D.; Tsang, S.C. Ultra-thin porous silica coated silver-platinum alloy nano-particle as a new catalyst precursor. Chem. Commun. 2003, 1522-1523. [CrossRef]

31. Marage, P.; Langlet, M.; Joubert, J. A new route for the deposition of $\mathrm{SiO}_{2}$ sol-gel coatings. Thin Solid Films 1994, 238 , 218-227. [CrossRef]

32. Hermida, L.; Abdullah, A.Z.; Mohamed, A.R. Synthesis and Characterization of Mesostructured Cellular Foam (MCF) Silica Loaded with Nickel Nanoparticles as a Novel Catalyst. Mater. Sci. Appl. 2013, 4, 52-62. [CrossRef]

33. Rimsza, J.; Jones, R.; Criscenti, L. Interaction of NaOH solutions with silica surfaces. J. Colloid Interface Sci. 2018, 516, $128-137$. [CrossRef] [PubMed]

34. Kahn, B.; Smith, D.K.; Straub, C.P. Determination of low concentrations of radioactive cesium in water. Anal. Chem. 1957, 29, 1210-1213. [CrossRef] 